\title{
Popular Adult and Labor Education Movement in Sweden-History, Content, Pedagogy
}

\author{
Petros Gougoulakis \\ Stockholm University
}

\begin{abstract}
In Sweden, workers' education-Arbetarbildning - is part of the all-embracing popular adult education movement that assumed its organizational consolidation in the late 1800s. Popular education-Folkbildning - is a culturally determined practice of social communication with roots in the Reformation and the Enlightenment, playing a decisive role in the shaping of the Swedish labor movement in the late 1800s, the history of which is intertwined with democratization and the transformation of Sweden into a highly developed welfare society. The pedagogical and ideological configuration of labor education in Sweden is surveyed from a historical perspective through the lenses of the Workers' Educational Association (ABF) and the labor movement's most powerful branches: the Social Democratic Party (SAP) and the Swedish Trade Union Confederation (LO). Workers' education was utilized as a political strategy for a just and equitable society, via successive reforms, based on knowledge and initiated and supported by well-informed citizens.
\end{abstract}

Swedish folkbildning (popular education), as we know it today, arose during the second half of the nineteenth century in the wake of industrialization and the rise of democratic social movements. It was the outcome of a long process of cultural evolution, characterized by constant power struggles between different social groups. It is possible therefore to undertake a brief archaeology of Swedish popular education, exploring different strata from at least the Reformation forward. The results of this exploration provide an essential perspective on its development and illustrate the importance of popular education for the collective organization and empowerment of working-class Swedes. This article will first outline the principal milestones and contours of Swedish popular education down to the present day, with a focus on its organization, contextual targeting, and pedagogical/philosophical characteristics, and then go on to highlight its current and future challenges.

\section{Tracking the Sources of Folkbildning: From Education for the People to Education by the People}

Throughout much of Sweden's early history, the Swedish Church exerted almost total control over the Swedes' collective moral upbringing, thought, and behavior. After the Reformation of the sixteenth century and with greater intensity during the next 100 years, Lutheran priests conducted home visits to monitor, 
inter alia, the parishioners' literacy, their biblical knowledge, and skills in reciting and recounting their knowledge of Luther's Small Catechism. ${ }^{1}$ State officials eventually realized that these home visits could also be used to count and monitor the population in other ways and in 1686 they enacted a "law on church registration" (lagen om kyrkobokföring) for the whole country, which charged priests with more tasks in connection to home visitations, such as collecting demographic information about every parishioner and keeping records in the parish catechetical register (husförhörslängden). Although intended principally as a population register, these data also became a useful tool in the church's preaching, in maintaining church discipline, and in promoting public health. The church books contained highly accurate and detailed records of parishioners' birth, baptism, marriage, death (including the causes), disease, disability, tax capacity, character (with notes on personal traits that the priest had noticed), drunkenness, population movements, activity, occupation, participation in the Eucharist, and ratings for catechetical knowledge, as well as notes on reading or literacy. ${ }^{2}$

One effect of the Swedish Reformation, which the Church Act of 1686 helped to document, had been a higher rate of literacy compared to that of other European countries. By the mid-1700s more than eighty percent of the population in Sweden could read, while the equivalent share was only fifteen percent in Central Europe. ${ }^{3}$ This increased literacy was one of the many changes that accompanied the Swedish people's shift toward the Evangelical-Lutheran church during and after the Reformation. Increased literacy was by no means encouraged in order to develop knowledgeable and independent citizens; rather its aim was to teach ordinary people to assimilate the main texts of Christianity. The increased literacy did make it possible for more people to read the Christian scriptures on their own, without a priest's enforced presence. But it also made it possible for them to interpret the texts in their own ways, as well as to read other, more "harmful" texts of which the church certainly disapproved. ${ }^{4}$

In this era inquisitive believers gathered in so-called "conventicles" throughout the country, where they studied the Bible in groups and made worship arrangements. Readers or "conventiclers," as participants were usually called, developed insights and learned a lot in the conventicles' nonthreatening dialogic milieu. One of the things they learned was that they could understand the content of the scriptures on their own, without any supervising intermediary. ${ }^{5}$ Over time, the autonomous conventicles grew in both scope and intensity. Worried by these developments, church authorities secured a Royal Decree in 1726, which imposed more stringent requirements concerning biblical interpretations. ${ }^{6}$ The decree barred parishioners from reading the Bible in groups and interpreting the text without the participation of a priest.

Once people could read, however, and believed in their own ability to interpret the Bible, the church was powerless to prevent the conventiclers from meeting. The more the clergy tried to assert its power over people, the more people, especially the literate and the faithful, resisted their oppression. The 
resistance then gradually grew into a revolt against various kinds of injustices. "Readers," influenced by various radical revivalist movements, began preaching the value of human dignity and fraternity.

The extensive reach of this revivalist culture eventually paved the way for later social reform movements, especially the temperance and the labor movements. The personal values and ideals of the revivalists, beliefs apart, were similar to those embraced by many activists in these later movements. All three, for example, stressed the importance of "skötsamhet" or "good character," a complicated combination of industriousness, moderation, sobriety, thoughtfulness, and reliability. ${ }^{7}$ The educational culture of the revivalist groups also carried over to the educational efforts of the temperance and labor movements, eventually crystallizing into what we know today as "study circles." 8 The study circle, like a conventicler group, emphasizes dialogue and discussion with one's peers as the best way to understand the world and how to be in it. The goal in each case is to create and sustain an alternative public arena. The revivalist movements, of course, focused more on their vision of a transcendental, postmortem world, whereas the temperance and labor movements focused on improving people's life in this world. ${ }^{9}$ But reading in study circles encouraged a reflective attitude, as well as collective learning, as participants read common material and talked with one another in order to make sense of what they were reading. As we shall see below, just such a pursuit of knowledge and education in a study circle environment became a key strategy of the labor movement as it worked to fulfill its social vision.

Two additional intellectual currents need to be added to the picture before we can properly understand the roots of folkbildning in Swedish culture. They are the Enlightenment of the eighteenth century and the New Humanism of the nineteenth century. Enlightenment's advocates, also known as philosophes, attacked the dominant authority figures of traditional society, especially the nobility and the church. They constantly inveighed against the paralyzing influence of nobles and the clergy on the progress of science and the ability of people to think for themselves. Reason and experience, they argued, rather than revelation and scripture, ought to guide the search for knowledge. Rational understanding, grounded in experience, was essential in order to ensure individual happiness and social prosperity. In the political realm, such rational understanding meant the rule of law, the democratization of political authority, and recognition of the inalienable natural rights of each individual member of society.

The ideas and commitments of the philosophes had a lasting influence on European thought and a range of philosophical systems, including positivism and historical materialism. ${ }^{10}$ So, too, did the second major current behind the emergence of folkbildning: the "New Humanism" of Wilhelm von Humboldt, whose vision of education as personal development (Bildung in German) played a key role. Bildung, according to Humboldt, involved the harmonious development of an individual's abilities, and the actualization of their humanity, through education. While the advocates of Enlightenment focused more on free thought and critical thinking, the new humanists emphasized the 
importance of fostering individual development and personal growth. Both shared a faith in science and technology as the basis for social progress. But the New Humanists also encouraged the revival of classical languages and the study of the classical texts and languages as a complement to the new sciences. And the goal of both orientations was the same: human emancipation. Both the Enlightenment of the eighteenth century and the New Humanism of the nineteenth took human beings and actually-existing human societies as their point of departure. ${ }^{11}$ Social progress was the aim, but Bildung was its vehicle.

\section{The Dawn of the Swedish Labor Movement}

Sweden experienced dramatic demographic changes during the nineteenth and early twentieth centuries. Between 1850 and 1920 the Swedish population grew from 3.5 to 5.9 million. During the same period, just over one million people emigrated, mainly to the United States. Within the country, the urban population also increased sharply from ten percent of the whole in 1850 to almost fifty percent in 1920. Industrialization took off, as railways and other means of communication facilitated increased foreign and domestic trade. The proportion of the population living by agriculture fell from 72.4 percent in 1870 to 48.8 percent in 1910. The corresponding share of the nonagricultural sector, which was highly concentrated on iron ore and timber, rose from 27.6 percent to 51.2 percent of the workforce. ${ }^{12}$ A diverse working class consisting of mechanics, machine operators, small traders, craftsmen, miners, and lumberjacks gathered together in the new industrial towns that grew up along the coast and the railroad lines. In addition, a large number of landless farm laborers settled on the outskirts of the new towns, where they constituted a reserve labor force for the expanding industrial economy. ${ }^{13}$

These changes in Swedish society gave rise to new collective needs and interests, which encouraged the growth of new working-class movements with economic, social, ideological, and political aspirations. Among the important influences on the early Swedish labor movements were the French utopian socialists and German communists, especially those grouped around the Communist League, on behalf of which Karl Marx and Frederick Engels wrote their Communist Manifesto. A Swedish translation of the Manifesto, attributed to the socialist Per Götrek, appeared in 1848, the same year as the German original. Götrek and his comrades had close relations with Europe's socialist movements and participated actively in Stockholm's education circle (bildningscirkel). ${ }^{14}$

The Stockholm circle had been founded in 1845 by the master tailors Olof Renhult and Sven Trägårdh and the physician Johan Ellmin, in order to raise the workers' level of education and facilitate interaction between the classes. Renhult, Trägårdh, and Ellmin modeled the Stockholm education circle on similar English and German initiatives. Its program was popular, scientific, and basically apolitical. Its members consisted largely of craft journeymen. A few years later, Götrek and Ellmin, together with another tailor, Carl Rudolf 
Löwstädt, launched the Scandinavian Society, which was accused of advocating communism and subversive activities and dissolved after only one year. ${ }^{15}$ Craftsmen and journeymen, who had been inspired by Étienne Cabet's and Saint Simon's utopian socialism doctrines (which united communitarian and Christian principles), were a majority of the Society's active members. ${ }^{16}$ These same enthusiasts were also active in other organizations, such as the Society for the Promotion of Worker Associations, all of which aimed to stimulate and maintain interest in educative pursuits among the workers.

These pioneer efforts were short-lived and did not result in lasting political or trade union institutions. Other more permanent forms of organization did develop during the second half of the nineteenth century, however, including arbetareinstitut (workers' institutes) and arbetareföreningar (workers' associations). They were generally "top-down" initiatives. Their goal was primarily to "refine" or "improve" workers so that they could become "mature" enough to participate in politics. Later in the century, some of these associations also sought to encourage friendly relationships between employers and employees and to discourage the growth of independent labor organizations. ${ }^{17}$ They were all animated by the notion of worker self-help. Through study and the pursuit of "cultivated pleasures," workers were to develop the capacity to raise themselves out of their social and economic misery. Among other activities, some worker associations also ran consumer cooperatives, credit unions, and pension funds to improve the members' living conditions.

Inspired by Comte's positivist doctrine, many liberal and radical gentlemen also experimented with educational circles and lectures that could disseminate scientific knowledge and information to all social classes, especially the working class. In keeping with this tradition, Anton Nyström, another physician, started a workers' institute in 1880 in order to help workers improve the quality of their lives through education. ${ }^{18}$ Scientific knowledge, including social scientific knowledge independent of all political and religious standpoints, was central to the institute's curriculum. Only educated citizens who understood their obligations, as well as their rights, and who exemplified a new social ethic would be able to build a new society on the basis of scientific truth and understanding. The effort inspired its followers. But many workers and workingclass spokesmen criticized Nyström's positivist faith and accused him of not only trying to found a new religion, but also of suppressing workers' desire to agitate to improve their working conditions and living standards. ${ }^{19}$

\section{From Utopia to Pragmatism}

During the first decades of the mid-1800s the modern Swedish trade union movement lacked a clear ideological identity and oscillated between liberal and socialist (or social democratic) positions. Socialists, led by August Palm, wanted a socialist Sweden. They saw unions as essential constituents of the socialist society of the future and therefore encouraged their organization and growth. The socialists also agitated for universal suffrage, which they saw as 
critical in order to elect governments that could enact the policy reforms required to create a socialist society. ${ }^{20}$ Liberals, on the other hand, who dominated the movement in the second half of the nineteenth century, believed that the solution to the "labor question" did not lie in a transition to socialism, but in the moral, intellectual, and economic uplift of the working class within a capitalist society. They supported strikes as a last resort but stressed that neither workers nor employers had anything to gain from them. The liberals also insisted that the trade unions should avoid making commitments to a particular political party. The chief aim was to prevent conflicts between labor and capital. ${ }^{21}$

The rivalry between the liberal and socialist wings of the labor movement continued from the mid-nineteenth century into the first decades of the twentieth, when the socialists eventually won the argument, at least among a majority of the most active workers, who became staunch supporters of the socialist cause. Palm insisted that the only way for workers to gain the power required to build a socialist society was to unite in a single, large organization, which would function as both a political party and a trade union federation. He characterized such a prospect as "an event of epoch-making significance." 22

After countless contacts, talks, and negotiations with trade union organizations, delegates from all worker organizations and worker-centered associations that supported social democratic principles were invited to a nationwide congress in 1889. There they agreed to found the Social Democratic Workers Party of Sweden (SAP: Sveriges socialdemokratiska arbetareparti). Overall, a total of seventy organizations were represented at the meeting, of which fifty were trade unions. Not all of the unions were willing to affiliate directly with the party, however, and the question of whether the labor movement's political and trade union branches ought to be merged into one organization continued to be debated for several years.

Finally, in 1898, 270 delegates from 24 trade unions representing 50,000 organized Swedish workers met to found an independent national Swedish trade union federation, the Landsorganisationen $i$ Sverige (literally, the National Organization of Sweden, now known as the LO). ${ }^{23}$ A majority of the delegates then also approved a proposal that all members of the LO automatically become, initially, members of SAP. The arguments that the political and the trade union wings of the labor movement should unite to fight the attacks on freedom of association and universal suffrage proved to be convincing. But the unity was achieved on the basis of two separate organizations. ${ }^{24}$ The LO and the SAP have dominated Sweden's political and social life ever since.

\section{Arbetarnas Bildningsförbund (ABF) - Labor Movement's Educational Movement}

The Swedish labor movement cannot be understood without a study of popular education, which was a movement in its own right operating both alongside and within the labor movement. Throughout its history, in fact, the Swedish social democratic labor movement has often seemed to be a huge educational 
project. During the twentieth century, the socialist labor movement expanded the popular education activities of the nineteenth-century liberal worker institutes and associations to embrace even the lowest rungs of the social hierarchy. Workers from different parts of the labor movement-political associations, trade union clubs, and cooperative societies - came together to educate themselves and exchange life experiences. In these clubs, they came in contact with political and ideological currents of equality, justice, and solidarity; learned the practical application of democratic rules and processes; and developed the ability to organize, lead, and exercise democratic control. Many of the SAP's most prominent politicians and leaders got their first education in trade unions. $^{25}$

Many attempts had been made to bring together all of the labor movement's educational and study activities under one roof. But the passage of the 1912 Library Reform Act accelerated the process. The law stipulated that national organizations that maintained libraries for public use in various parts of the country were eligible for government grants equal to half the cost of their book budget. The legislature intended in this way to encourage the dissemination of knowledge on various useful topics and to "foster and shape viable as well as socially useful citizens."

The Library Reform Act of 1912 was a milestone in the history of folkbildning in Sweden. The state's involvement helped to create a system of central libraries with branches in almost every municipality, evenly distributed throughout the country. In addition, because the subsidies applied only to nationwide organizations with at least 20,000 members, the law encouraged local educational associations to band together. The first such national educational association was the Workers' Educational Association (ABF: Arbetarnas bildningsförbund), founded in 1912. It emerged as the rational organizational expression of the already-existing educational work carried out within the labor movement, such as LO, SAP, Cooperative Association, and the Social Democratic Youth League. ${ }^{26}$ These were the constituent members, the "ownership base," of ABF. Since then the ownership base has expanded, comprising today fifty-nine national civil society organizations, whose common denominator is that they share the values of the labor movement. ABF's foundation confirmed the immense importance of popular education for the realization of a social democratic society, which in theory was "not only based on a system of the highest technical perfection of management," but also relied on the power of "highly cultured people."27

ABF appealed to all workers regardless of organizational affiliation and was a meeting place for ideological dialogue and cooperation with different points of view. It arose and still operates as an educational "metaorganization" for all labor movement organizations. The formation of ABF answered a real need within the labor movement for a separate educational institution that did not reproduce the ruling bourgeois society. However, the labor movement's various branches did not always coexist harmoniously within the same educational institution and could not be taken for granted. Different opinions 
existed concerning both organizational structure and educational content. ${ }^{28}$ Despite the power struggle within the ABF between leftist organizations on the one hand, and SAP and LO on the other, however, which the latter won, $\mathrm{ABF}$ did not split into competing educational organizations. Instead, it remained open to ideological, political, and subject-related diversity and gave the different organizations within it pedagogical freedom in the arrangement of their study plans.

Almost all education within LO and SAP is organized under the auspices of $\mathrm{ABF}$. This is due in part to the restrictions placed by the state on the financial support it provides for the political and trade union education. From the beginning, state grants were not paid to activities that were considered political or ideological. Only programs that were "free and voluntary" 29 and met the requirement of objectivity could be funded. The founding of ABF, as well as other educational associations, in effect enabled various political and religious movements to evade these funding restrictions, which were loosened somewhat in the 1960s and 1970s, when grants also could be allocated to "profiled study activities." 30 Throughout the period, however, the bonds between the study associations and civil society organizations were recognized as "actively contributing to strengthening and developing democracy in our country." 31

The LO also conducted part of its internal education under its own management in six so-called LO schools spread across the country. The most famous is Brunnsvik in northern Sweden, which opened as a regular folk high school with a strong labor movement profile in 1906 and six years later hosted the meeting at which the ABF was founded. ${ }^{32}$ In 1929, the LO began to offer its own courses at Brunnsvik. From the point of view of its students, the school's dual function as a folk high school and an LO education center was practically indistinguishable. Many LO members attended both the regular folk high school and LO courses. Brunnsvik became a symbol within the labor movement, held in high regard for providing its branches with welleducated functionaries and devoted activists. ${ }^{33}$

$\mathrm{ABF}$ is today the largest of ten study associations in Sweden and is an essential part of the national infrastructure for lifelong learning, with branches in every municipality across the country. Each local branch is its own legal entity and provides affiliate groups with premises, educational materials, pedagogical advice concerning learning methods, and relevant content. (Affiliating organizations have always been able to specify the objectives of their own education.) $\mathrm{ABF}$ is also organized at the regional level in districts, where study circle facilitators and organizers are trained. At the national level, the National Secretariat shoulders the strategic responsibility for the development of the organization, keeps in touch with its partners, analyzes their study needs, and works politically to promote liberal adult education for all citizens. It also pursues an active international agenda.

The most distinctive feature of $\mathrm{ABF}$ as a folkbildning organization is its commitment to democracy and to the autonomy of its participants. ABF shares the labor movement's social vision but is otherwise independent and 
cooperates freely with a wide range of other social movements around common projects. The organization's ethos is captured by its ideological principles, which underscore its profile as "a radical idea movement." 34 It also fully shares the official state view on the importance of popular adult education. The ABF conducts its study activities on the basis of a broad commitment to equality, solidarity, and democracy. In accordance with those principles, it seeks to promote social transformation consistent with the fundamental values of the labor movement; to educate the members of the affiliated organizations for missions in associations, the working life, and society; and to create the conditions for participation and freedom of choice in education and cultural life for all citizens. Following is its most recent "program of ideas":

Our basic outlook is the unique and equal value of every individual. Our goal is to strengthen and extend democracy in all areas of social life. Our ambition is to bring about a society and a world in which human values come before market values.

Our vision is a society and a world free of all forms of oppression and injustice and which affirms the equal right of everyone to be different. Our basic task concerns the emancipation of all people - both individually and collectively.

Liberal adult education is for us an idea about a free quest for knowledge that can give people the courage and knowledge to assume power and responsibility both in their daily lives and in society as a whole. We believe in the potential of radical liberal adult education to question and to be democratic force for change.

We are convinced that we can influence the future and that another world is possible. $^{35}$

\section{The Labor Movement in Government-Social Democracy and the Swedish Model}

After an intense period marked by frequent strikes and violent conflict, the Swedish political and trade movement emerged as the dominant factor in the political life of the country. ${ }^{36}$ It did so by gradually instilling in its membership a new reformist, social democratic political culture, oriented toward cooperation, pragmatism, compromise, equality, and modernization, which enjoyed massive grassroots support across the nation. The labor movement in effect wrested the project of modernization from the non-Socialist parties and launched the largest social transformation in modern Swedish history. It also put its own stamp upon this project by linking it to the building within Sweden of a folkhem-a "people's home." ${ }^{37}$ Neither the widespread support for the project nor its realization would have been possible without the labor movement's intense and persistent popular education work among its rank-and-file and the population at large.

Its efforts were so successful that the Social Democratic Party (SAP) governed Sweden continuously from 1932 to 1976, the longest mandate ever given a working-class party in the West. During this period, it enjoyed almost total 
ideological hegemony over a wide array of Swedish social institutions. The decisive event in the consolidation of the SAP's power was, without doubt, the landmark agreement between the LO and the Swedish Employers' Federation (SAF) in Saltsjöbaden in 1938. As a result of this "historic compromise," labor and capital pledged to resolve any of their future difference through negotiations. The Saltsjöbaden agreement was a concrete manifestation of the labor movement's decision to opt for peaceful industrial and social reforms instead of revolution and violent upheavals. ${ }^{38}$ It confirmed the labor movement's hegemonic position in Swedish society and underlined the legitimacy of the Social Democratic welfare state project - the folkhem - as an overriding interest.

In the 1960s, the post-World War Two spirit of social consensus was strained in new ways, as migration and internationalization increased. Technological change also altered the conditions of production and demanded new skills. New radical social forces, which were less interested in economic growth than in the need for personal integrity and self-realization, also entered the political arena. The demand for adult education programs grew. New laws required nine years of compulsory schooling and expanded access of upper-secondary education. Targeting society's "talent pool," the goal of these reforms was to provide an adequate supply of skilled workers to meet the needs of a changing labor market. While education in general was still intended to promote individual and social development as well as economic growth, adult education in particular was justified as a way to ensure the equitable distribution of educational opportunities. ${ }^{39}$ In response to these changes, the LO and ABF initiated many adult education reforms in the late 1960s, which were encouraged and supported by the social democratic government, including funding for outreach activities to educationally disadvantaged adults, many of whom were immigrants. ${ }^{40}$

The Swedish labor movement and its social democratic folkhem project continued to make gains in the early 1970s. The 1973 elections resulted in a 50-50 split between the socialist and bourgeois parties in Parliament. Even so, an impressive series of prolabor laws were enacted, including employee representation on company boards, ${ }^{41}$ enhanced powers for safety stewards, and tighter rules on layoffs and firings. ${ }^{42}$ The Act on Co-determination (MBL) passed in 1976 further strengthened the union's positioning in relation to employers. ${ }^{43}$ It also represented the high-water mark of postwar Swedish social democracy. In the mid-1970s, the employers' federation orchestrated and financed a fierce campaign against what it viewed as a bloated public sector and called for the restoration of market forces. The campaign was sparked, in part, by a proposal for "wage-earner funds" (löntagarfonder), financed by a tax on "excess profits," which were to be under the control of the unions. ${ }^{44}$ The SAF's attacks proved successful, and the SAP lost its Parliamentary majority in 1976, the first time in forty-four years, paving the way for tax cuts, the selling off of state enterprises, and the extensive deregulation of business and the financial sector.

In response to the employers' offensive, the SAP and the unions began to conduct extensive internal membership education. The party's efforts focused 
on reminding members, especially new ones, of the history of the social democratic movement and its ideology. According to Tomas Eneroth, a group leader of the social democratic parliamentary group, head of SAP's internal education, and a member of the ABF executive committee, "a social democrat must know why he/she is a Social Democrat." 45 There was also a growing awareness of the importance of ensuring that the SAP was "a learning organization," not least because of the experience of recent years, in order to strengthen the quality of the meaningful and competent membership:

Governmental power is only on loan but SAP, as an organization, is its members. We need not only care for our members when we are in opposition, but even more when we are in government. The problem with membership education earlier, with the party in power, was that many things were taken for granted. The prevailing attitude was that such a thing as 'education' is handled elsewhere. We can no longer rely on others, e.g. the government, to 'resolve' the political training of our members. The party must more clearly than before, be linked to its popular movement history and, not least, to the Social Democratic Youth Association's strong tradition of education within popular movements. ${ }^{46}$

SAP member education, even though it is by definition political education, continues to be conducted in cooperation with the ABF and LO. ${ }^{47}$ As Eneroth observed, organizational development and the internal education go hand in hand. The aim of the SAP's internal education today is not primarily to focus on developing a cadre of functionaries. It is to live up to the party's popular movement tradition by empowering all members. In particular, membership education tries to reach those who have only just joined the party and may have only just moved to the country. The SAP's leadership believes that it is vital that they familiarize themselves with the Swedish popular movement model and with the country's political culture. They seek create a common frame of reference for all members, and for that to happen continuing educational work has to become a strategic concern for the Social Democratic Party. To assist with this effort the SAP has coordinated many of its study courses with the LO and ABF, folk high schools, and other labor movement-owned training facilities, such as Bommersviksakademin. $^{48}$

At present, the outcome of this effort is still unclear. The SAP has regained neither its clear majority in Parliament nor its social mandate. Political power in Sweden is for now precariously balanced between the liberal and the social democratic parties, while a growing number of voters are supporting the so-called Swedish Democrats, a right-wing, an anti-immigrant political formation which threatens all that the SAP has fought for over the last century.

\section{The Swedish Labor Movement: A Matter of Education}

The history of the Swedish labor movement is the narrative of a poor agrarian country's remarkable transformation into a modern, high-tech welfare state 
with well-functioning institutions and a transparent democratic system. Sweden's social infrastructure of opportunities is inclusive and creates the sheltered basis for all citizens' free development. This structure of opportunities rests on solidarity tax and redistribution policies that take into account people's differences based on the principle of all humans' equal value. The values of the labor movement appealed to far more citizens than just those who belonged to the working class, thereby creating a broad-based social contract. The contribution of popular education in general, and of ABF in particular, to the creation of modern Sweden is undisputed and widely recognized.

Folkbildning in Sweden developed in the wake of industrialism and was practiced in a very specific context marked by its history, cultural traditions, fixed power relations, and-not least-geographical and environmental conditions. Meeting, learning, and socializing in study circles proved to reflect a genuine Swedish pattern of social communication; it was neither too intimate nor too formal: it is lagom, "just right." Olof Palme, in a speech at the 1969 Congress of the Social Democratic Party, described Swedish political culture as follows:

Sweden is, basically, a study circle democracy. By means of study circles, generations have exercised themselves to make critical analyses to achieve reasonable decisions by working together without giving up their ideals in that process. It is often in study circles where proposals for changes in society have been formed. ${ }^{49}$

The Swedish "study circle democracy" is a country where "everyone can participate," a country were dreams find room to grow real. Thus, the country's current minister of education, Aida Hadzialic, who came to Sweden as a refugee with her parents from the Bosnian War in the late 1990s, has observed:

We tend to talk about the American dream. I want to emphasize the Swedish dream. The social democratic welfare model, which included me as a war-affected child in a family without the ability to pay for any schooling. I would not have such an opportunity in other systems. This is the greatness of the welfare society. I am grateful! ${ }^{50}$

Without the contributions of Swedish popular education and folkbilding, there might not have been a "freedom dream." At the very least, it would be a very different dream, indeed.

\section{NOTES}

1. The Reformation in Sweden refers to the conversion of the medieval Catholic Church in Sweden to the Evangelical Lutheran Swedish Church during the period 1527-1600. The Reformation marks the end of the Middle Ages and the birth of modern independent Sweden (William Gilbert, Renaissance and Reformation, Chapter 12: The Reformation in Germany and Scandinavia (Lawrence, KS, 1998), see http://vlib.iue.it/carrie/texts/carrie_ books/gilbert/12.html (accessed October 17, 2015). Martin Luther, The Small Catechism, 
trans. Robert E. Smith. (Project Wittenberg, [1529] 1994). See http://bookofconcord.org/smallcatechism.php (accessed July 20, 2015).

2. "Husförhör" [parish cathedrical meeting], in Nordisk familjebok (second edition, 1909). http://runeberg.org/nfbk/0707.html (accessed July 20, 2015). The parish catechetical register is nowadays a very useful tool in genealogical research.

3 . The regulation on catechetical meetings was repealed in 1888 . The meetings, however, survived until 1900 because they fulfilled an important function in the service of Christian education. Inge Johansson, Bildning och klasskamp. Om arbeterbildningens förhistoria, idéer och utveckling (Stockholm, 2002).

4. Johansson, Bildning och klasskamp; Egil Johansson, "The History of Literacy in Sweden," in Literacy and Social Development in the West-A Reader, ed. Harvey J. Graff (Cambridge, 1981), 151-82.

5. See Petros Gougoulakis, "Studiecirkeln. Livslångt lärande...på svenska!” [Study Circle. Lifelong Learning ... in Swedish] (Ph.D. diss., Stockholm University, 2001); Petros Gougoulakis, Bildning och lärande. Om folkbildningens pedagogik. [Bildung and Learning. On the Pedagogy of Popular Education] (Stockholm, 2006).

6. Tore Frängsmyr, Svensk idéhistoria: Bildning och vetenskap under tusen år, Del II 18092000, (Stockholm, 2004), 91-92. See also "Konventikelplakatet," in Nordisk Familjebok, http:// runeberg.org/nfah/0657.html (1884, accessed July 21, 2015). Conventicler (Middle English, from Latin conventiculum, meeting, diminutive of conventus, assembly) is a religious meeting, especially a secret or illegal one. Such meetings were also held by Dissenters in England and Scotland in the sixteenth and seventeenth centuries, www.thefreedictionary. com/Conventicler (accessed July 21, 2015). The proscription of the conventiclers ended in 1858.

7. Ronny Ambjörnsson, Den skötsamme arbetaren. Idéer och ideal i ett norrländskt sågverkssamhälle 1880-1930 ( Stockholm, 1998); Stefan Gelfgren, "Väckelse som folkbildning," Forskning om folkbildning 2 (2005): 3-16.

8. Erik W. Gatenheim, Studiecirkeln 75 år : bildningsarbetet $i$ nykterhetsrörelsen med utblickar till andra folkrörelser (Stockholm, 1977); Ture Nerman, Studiecirkeln. Historik kring ett halvsekelminne (Stockholm, 1952); Robert Höghielm, "Undervisning i komvux: ideal och verklighet i grundskolekurser" (Ph.D. diss., Högskolan för Lärarutbildning i Stockholm. Institutionen för pedagogik, 1985); Bo Andersson, Folkbildning $i$ perspektiv. Studieförbunden 1870-2000. Organisering, etablering och profilering, Stockholm, 1980.

9. Gelfgren, "Väckelse som folkbildning."

10. See Poul Lübcke, Filosofilexikonet (Stockholm, 1988); Sven-Eric Liedman, I skuggan av framtiden. Modernitetens idéhistoria (Stockholm, 1997); Ingvar Johansson and Sven-Erik Liedman, Positivism och marxism (Stockholm, 1981).

11. Comte's positivism and his associated positive education program, in particular, influenced the theory and practice of Swedish popular education. Since the late 1960s the term positivism has symbolized one particular research approach. It was subjected to sharp criticism in academia and in some circles was perceived as a synonym for a rigid and outdated research paradigm. But Comte's positivism was quite different from what it is accused of today. The search for nature's and society's laws was Comte's scientific program and his worldview was based on scientific evidence. The discovery of laws and regularities in nature and society constituted the basis for an almost unbridled optimism, a belief that it was possible to explain in order to intervene. Positivist doctrine took a distance from all kinds of metaphysics and theological dogmas. Virtue and morality, reason and harmony, purity and order, altruism, and "sociality" were qualities that positivism espoused. A phrase borrowed from Andersson (Folkbildning i perspektiv) can summarize the positivist philosophy and educational ideal, "order without restoration and progress without upheaval."

12. Åke Isling, "Kampen för och mot en demokratisk skola. 1: Samhällsstruktur och skolorganisation" (Ph.D. diss., Stockholm University, 1980), 168-73.

13. Per Gustavsson, Lars Rydquist, and Åke Lundgren, Mera ljus!: socialdemokratins kultursyn fram till andra världskriget (Stockholm, 1979).

14. To avoid prosecution and withdrawal of the publication, Götrek brought into the text some modifications: The title was changed to The Voice of Communism and the slogan "Proletarians of All Countries, Unite!" was replaced with "The voice of the people is the voice of God!" Knut Bäckström, Arbetarrörelsen i Sverige (Stockholm, 1977); Gunnar Richardson, Kulturkamp och klasskamp: ideologiska och sociala motsättningar i svensk skoloch kulturpolitik under 1880-talet [Cultural struggle and class struggle: ideological and social 
conflicts in Swedish educational and cultural policy in the 1880s] (Ph.D. diss., University of Gothenburg, 1963), 262.

15. Gustavsson, Rydquist, and Lundgren, Mera ljus, 46.

16. Journeyman wanderings were abolished in 1844. See also article by Peter Cornell, "Peter (Per) Götrek," in Svenskt biografiskt lexicon, http://sok.riksarkivet.se/sbl/artikel/13467 (accessed July 24, 2015).

17. Lars Olsson and Lars Ekdahl, Klass $i$ rörelse-arbetarrörelsen $i$ svensk samhällsutveckling (Stockholm, 2002).

18. Gunnar Rickardson, "Kulturkamp och klasskamp. Ideologiska och sociala motsättningar i svensk skol- och kulturpolitik under 1800-talet" [Cultural struggle and class struggle: ideological and social conflicts in Swedish educational and cultural policy in the 1880's] (Ph.D. Göteborg: Akademiförlaget, 1963).

19. Sigfrid Leander, Folkbildningens födelse: Anton Nyström och Stockholms arbetareinstitut 1880-1980 (Stockholm, 1980).

20. August Palm (1849-1922) was one of the founders of the social democratic labor movement in Sweden, leading it in a reformist direction. He belonged to the party's left wing.

21. Johansson, Bildning och klasskamp.

22. Ibid, 150.

23. Olsson and Ekdahl, Klass $i$ rörelse-arbetarrörelsen $i$ svensk samhällsutveckling.

24. For many decades the LO was criticized by right-wing political parties for obliging the trade unions to collectively affiliate their members to the Social Democrat Party. However, the individual members had the right to withdraw from the party. Sven Lundkvist, Folkrörelserna $i$ det svenska samhället 1850-1920 (Stockholm, 1977); Hilding Johansson, Folkrörelserna i Sverige (Stockholm, 1980). This practice, based on a decision from 1890, ended in 1990/1991. The present rule is that the local trade union organization can, in its capacity as an organization, affiliate to the party without the individual members becoming party members. Nonetheless, the LO still supports the Social Democrats economically and politically, by, for example, conducting joint campaigns with the Social Democrats, and the president of LO is a member of the executive committee of the Party.

25. Jonas Åkerstedt, Den litterate arbetaren: bildningssyn och studieverksamhet $i$ ABF 1912-1930 (Uppsala, 1967); Hugo Heffler, Arbetarnas bildningsförbund 1912-1962 : krönika vid halvsekelgränsen (Stockholm, 1962).

26. Heffler, Arbetarnas bildningsförbund 1912-1962.

27. From Rickard Sandler's pamphlet "Workers' School and Other Socialist Culture," quoted in Heffler, Arbetarnas bildningsförbund 1912-1962, 16, (own translation).

28. As early as 1919 the reformist organizations succeeded in achieving an overwhelming influence in the ABF Representatives' Meeting by virtue of their membership strength and that they accounted for eighty-five percent of the membership fees to the ABF.

29. Free and voluntarily refers to popular education activities that are independent of government or private interests and based on participants' learning needs.

30. In the early 1960s the government stated that among the main tasks of popular education organizations, which are rooted in social movements, were to create the basis of knowledge and skills, orientation and perspectives that are necessary for an informed and constructive public debate (Proposition 1963:36, Angående ökat stöd till studiecirkelverksamhet, m.m.; Arvidson, Folkbildning $i$ rörelse).

31. Andersson, Folkbildning i perspektiv; Proposition 1963:36, Angående ökat stöd till studiecirkelverksamhet, m.m.; Arvidson, Folkbildning i rörelse.

32. Folk high schools are independent adult education colleges. The Folk High School is a form of education that has existed in Sweden for more than 100 years. Unlike the Danish folk high schools (associated with N.F.S. Grundtvig, a Danish philosopher, poet, educational thinker, and clergyman) that offer nonformal adult education, the 154 folk high schools in Sweden mainly provide formal adult education based on the "free and voluntary" folkbildning tradition. To a large extent, the folk high schools are financed by grants from the state and county councils. About 110 of these are linked to various social movements and nonprofit associations and about 40 are operated by county councils and regions. See https://www.folkhogskola.nu/ Otherlanguages/English-engelska-2/ (accessed March 5, 2016).

33. ABF and LO operated Brunnsvik Folk High School jointly until 2009. Thereafter, the LO phased out its involvement, primarily for economic reasons, and in the summer of 2013, 
tragically, Brunnsvik ended all its educational activities. Politicians, trade union leaders, and writers had received their education and training in the school's historic red houses since 1906. Then, suddenly, a piece of labor history and one of the largest and award-winning folk high school libraries in the world just vanished. (See Svante Isaksson, "Kapad av kapitalet. Arbetarrörelsens klassiska folkhögskola slaktas och säljs ut," Aftonbladet Kultur, April 5, 2013, http://www.aftonbladet.se/kultur/article16543632.ab (accessed March 5, 2016). At present, the LO cooperates with fifteen other folk high schools, which are owned by various labor movement organizations at the local or central level. It also retains strong ties to ABF, which have recently again become even closer and stronger. The LO's current chairman, Karl-Petter Thorwaldsson, is a former president of ABF.

34. ABF, Another World Is Possible! (Program of Ideas, 2006).

35. Ibid.

36. Labor conflicts were very frequent in the 1920s, and Sweden had the highest strike rate among Western industrial countries. After the assumption of government by the SAP, the strikes gradually waned, and after World War Two Sweden had the lowest strike rate among similar countries (see Jenny Jansson, "Manufacturing Consensus. The Making of the Swedish Reformist Working Class" (Ph.D. diss., Uppsala University, 2012).

37. Francis Sejersted, The Age of Social Democracy: Norway and Sweden in the Twentieth Century (Princeton, 2011).

38. Petros Gougoulakis and Michael Christie, "Popular Education in Times of Societal Transformation-A Swedish Perspective," Australian Journal of Adult Learning 52 (2012): 237-56.

39. Rubenson Kjell, "The Swedish Adult Education Initiative: From Recurrent Education to Lifelong Learning," in International Handbook of Lifelong Learning, ed. David Aspin et al. (Dordrecht, 2001), 329-38; Rubenson Kjell, Tuijnman Albert, Wahlgren Bjarne, and Från Kunskapslyftet, Till en strategi för livslångt lärande (Stockholm, 1999); Kenneth Abrahamsson, ed., Hela vuxenutbildningen!. En framtidsbild i historiens ljus (Stockholm, 1992).

40. FÖVUX (Kommittén för försöksverksamhet med vuxenutbildning), Uppsökande verksamhet för cirkelstudier inom vuxenutbildningen (Stockholm, 1972); OECD, Thematic Review on Adult Learning: SWEDEN (2000), http://www.oecd.org/edu/innovation-education/ 2697896.pdf (accessed October 29, 2015).

41. See Anders Victorin, Employee Participation on the Company Board: The Swedish Experience, Company Law Reform in OECD Countries. A Comparative Outlook of Current Trends (Stockholm, 2000), http://www.oecd.org/daf/ca/corporategovernanceprinciples/ 1931982.pdf, (accessed October 22, 2015).

42. Jonas Pontusson, "Radicalization and Retreat in Swedish Social Democracy," New Left Review, 165 (1987): 5-33.

43. Lag 1976:580, Om medbestämmande i arbetslivet (MBL). MBL regulates collective labor law and the workers' right to require the workplace management to negotiate with the unions over any corporate decisions that would affect the workforce. The MBL act gave unions greater access to company records and priority of interpretation in contract disputes involving nonwage issues - a condition that raised the need for massive training of the union's trustees.

44. Löntagarfonder (wage-earner funds), were collectively owned and managed investment funds financed with corporate profits during from 1984 to 1992. LO launched the idea of wage-earner funds as a complement to a solidaristic wage policy, to break the wealth concentration in society and to strengthen the workers influence over the companies. The idea of taxing the companies' "excessive profits" and put them in funds under the control of the workers was awakened by the Metal Workers' Union in the 1971 LO congress. The concrete design of the löntagarfonder was drafted by the economist Rudolf Meidner and adopted at the 1976 LO Congress. Two years later, the SAP Congress also adopted the same proposal. After the election in 1991, the wage-earned funds were abolished by a center-right government coalition. See Ilja Viktorov, "The Crisis of Fordism and Wage-Earner Funds in Sweden" (Ph.D. diss. in Swedish/"Fordismens kris och löntagarfonder i Sverige"/, with summaries in English and Russian, Stockholm: Acta Universitatis Stockholmiensis, 2006); "Löntagarfonderrörelse kontra politik," http://www.marxistarkiv.se/sverige/roy_went-lontagarfonder.pdf (accessed March 5, 2016); Nationalencyklopedin, "Löntagarfonder," http://www.ne.se.ezp.sub.su.se/ uppslagsverk/encyklopedi/lång/löntagarfonder (accessed March 5, 2016).

45. Conversation with Tomas Eneroth, a group leader of the Social Democratic parliamentary group and head of SAP's internal education. 
46. Statement by Tomas Eneroth, own translation.

47. LO, Political cooperation, http://www.lo.se/english/political_cooperation (accessed October 25, 2015).

48. Campus Bommersvik is a center for advanced education, skills development, knowledge transfer, and labor market validation where the next generation of labor movement leaders are trained, http:/www.campusbommersvik.se/utbildningar/bommersviksakademin-18313816 (accessed August 1, 2016).

49. Olof Palme (1927-1986) was a Swedish Social Democratic politician, statesman, and prime minister.

50. See interview by Niklas Arevik, "Lång resa till Rosenbad" [Long journey to Rosenbad], Pedagogiska Magasinet, 2015-10-01, accessed March 5, 2016, http://www.lararnasnyheter.se/pedagogiska-magasinet/2015/10/01/lang-resa-rosenbad. 